\title{
Construction Safety Program for the National Ignition Facility
}

September 1, 2000

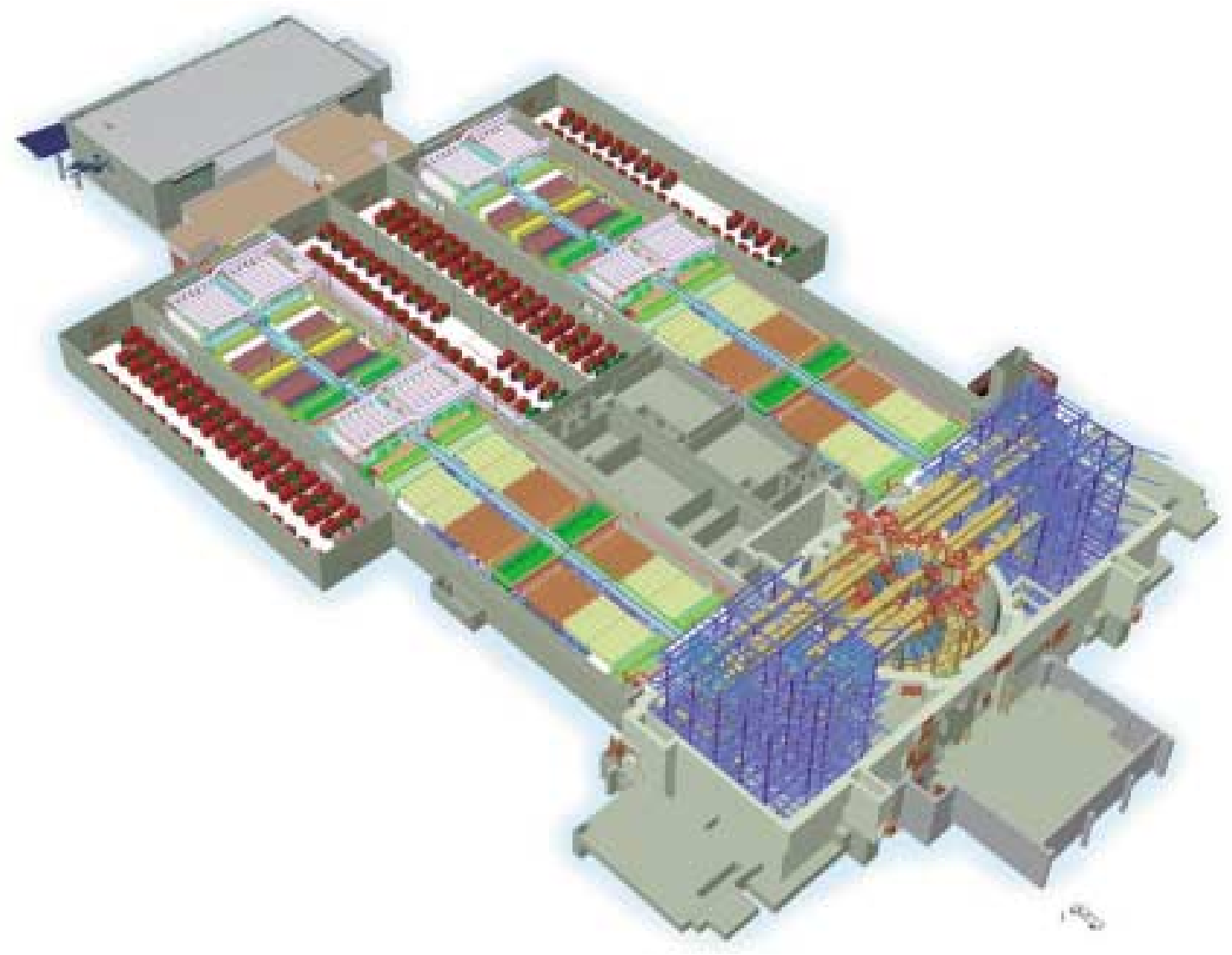




\section{DISCLAIMER}

This document was prepared as an account of work sponsored by an agency of the United States Government. Neither the United States Government nor the University of California nor any of their employees, makes any warranty, express or implied, or assumes any legal liability or responsibility for the accuracy, completeness, or usefulness of any information, apparatus, product, or process disclosed, or represents that its use would not infringe privately owned rights. Reference herein to any specific commercial product, process, or service by trade name, trademark, manufacturer, or otherwise, does not necessarily constitute or imply its endorsement, recommendation, or favoring by the United States Government or the University of California. The views and opinions of authors expressed herein do not necessarily state or reflect those of the United States Government or the University of California, and shall not be used for advertising or product endorsement purposes.

This work was performed under the auspices of the U. S. Department of Energy by the University of California, Lawrence Livermore National Laboratory under Contract No. W-7405-Eng-48.

This report has been reproduced directly from the best available copy.

Available electronically at http://www.doc.gov/bridge

Available for a processing fee to U.S. Department of Energy

And its contractors in paper from

U.S. Department of Energy

Office of Scientific and Technical Information

P.O. Box 62

Oak Ridge, TN 37831-0062

Telephone: (865) 576-8401

Facsimile: (865) 576-5728

E-mail: reports@adonis.osti.gov

Available for the sale to the public from

U.S. Department of Commerce

National Technical Information Service

5285 Port Royal Road

Springfield, VA 22161

Telephone: (800) 553-6847

Facsimile: (703) 605-6900

E-mail: orders@ntis.fedworld.gov

Online ordering: http://www.ntis.gov/ordering.htm

OR

Lawrence Livermore National Laboratory

Technical Information Department's Digital Library

http:/ / www.llnl.gov/tid/Library.html 


\title{
Construction Safety Program for the National Ignition Facility
}

\author{
Robert Predmore
}

September 1, 2000 
Approve:

Date:

Edward I. Moses

NIF Project Manager

Concur:

Date:

Valerie S. Roberts

Associate Project Manager

Beampath Infrastructure System

Concur:

Date:

Robert Predmore

Construction Manager

Beampath Infrastructure System

Concur:

Date:

Vaughn Draggoo

Commissioning and Operations Manager

Beampath Infrastructure System

Concur:

Date:

Sandra Brereton

Assurance Manager, NIF

Concur:

Date:

Michael G. Trent

Division Leader,

ES\&H Team 2 


\section{Contents}

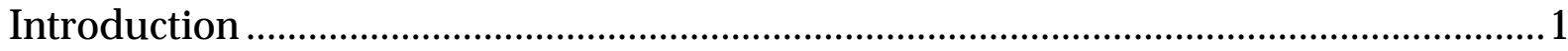

I. Safety and Health Policy for the National Ignition Facility during Construction ..... 1

II. Organization and Line Management Responsibilities..............................................4

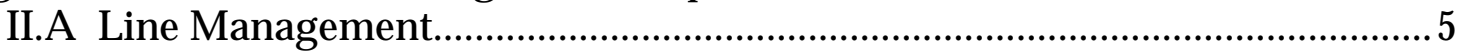

II.A.1 NIF Project Manager ................................................................ 5

II.A.2 Associate Project Managers (APMs).......................................... 5

II.A.2.1 Beampath Infrastructure System Associate Project Manager..6

II.A.2.1.1 Beampath Infrastructure System Construction Manager.......6

II.A.2.1.2 Beampath Infrastructure System Commissioning and

Operations Manager.............................................................. 7

II.A.2.1.2.1 BIS Commissioning and Operations Area Managers ......... 7

II.A.2.1.3 Beampath Infrastructure System Production Manager, Area Manager for Construction for NIF Staging Areas..........8

II.A.3 BIS IMI Construction Management Program Manager............... 8

II.A.3.1 General IMI Construction Manager............................................9

II.A.3.1.1 Area Manager for Construction ............................................. 10

II.A.4 Subcontractor/Sub-Subcontractor Project Manager..................10

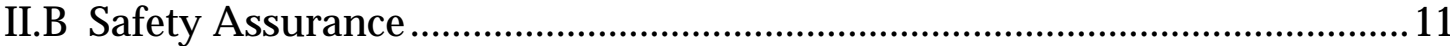

II.B.1 NIF Assurance Manager ......................................................... 11

II.B.1.1 NIF Safety Assurance Coordinator ........................................ 12

II.B.2 BIS Safety Manager ................................................................ 12

II.B.3 BIS IMI Project Safety Manager ................................................. 13

II.B.4 Site Safety Representatives ..................................................... 14

II.B.5 LLNL Environment, Safety, and Health Support ...................... 14

II.B.5.1 ES\&H Team 2.................................................................. 14

II.B.5.2 Emergency Management Division ........................................... 15

II.C NIF Workers ..................................................................................... 16

II.D Site Management Team ........................................................................... 16

III. Core Safety Management Processes ............................................................... 18

III.A Setting Management Expectations and Monitoring Work .......................18

III.A.1 Contractor Pre-Qualification and Post-Evaluation Process.....18

III.A.2 Safety Rewards Process............................................................. 18

III.A.3 Safety Discipline Process.........................................................19

III.A.4 Site Orientation Safety Training.................................................19

III.A.5 NIF Conduct of Operations and Safety Management

Training .............................................................................19

III.A.6 Walkabout Process for Evaluating Safety Implementation .....19

III.B Work Planning and Authorization Process.........................................20

III.B.1 Area Management Organizational Structure and Process .......20

III.B.2 Job Hazards Analysis (JHA) Procedure ...................................21 
III.B.3 Safe Plan of Action (SPA) Procedure ..........................................22

III.B.4 NIF Construction Site Work Authorization Procedure ............22

III.B.5 Incident Investigations and Lessons Learned ...............................22

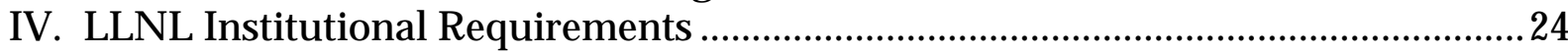

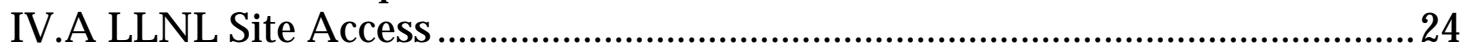

IV.B Drug Free Work Place Program .....................................................................24

IV.C NIF LLNL Safety Requirements................................................................25

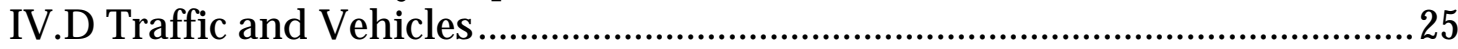

IV.E Stop-Work Authority and Procedures ..........................................................25

IV.F Permits and Authorizations ........................................................................26

IV.G Incident Notification, Reporting and Investigation.....................................26

IV.G.1 DOE Occurrence Reporting Requirements................................27

IV.G.2 Injury Reporting and Retention................................................2

IV.H Environmental Requirements..................................................................28

IV.H.1 National Environmental Policy Act............................................28

IV.H.2 Digging....................................................................................... 28

IV.H.3 Historical/Archeological Materials ………..................................28

IV.H.4 Hazardous Materials...................................................................29

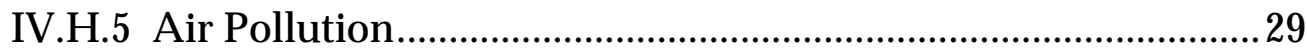

IV.H.6 Endangered Species.......................................................................29

IV.H.7 Storm Water Pollution Prevention Plans: ........................................29

IV.I Emergency Response and Notification ........................................................... 30

IV.I.1 Emergency Assistance Procedures.................................................30

IV.I.2 Medical Services and First Aid ......................................................30

IV.J Disaster Response...................................................................................

IV.J.1 Self-Help Planning........................................................................ 31

IV.J.2 NIF Self-Help Plan - NIF Emergency Procedures........................32

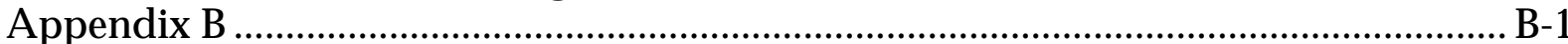

IV.J.3 Flooding ……………………................................................ 32

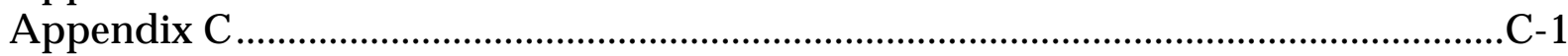

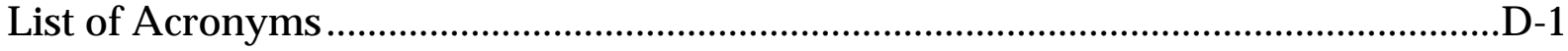




\section{Introduction}

This Construction Safety Program (CSP) for the National Ignition Facility (NIF) presents safety protocols and guidelines that management and workers shall follow to assure a safe and healthful work environment. Appendix A, a separate companion document, includes further applicable environmental, safety, and health requirements for the NIF Project.

Specifically this document:

- Defines the fundamental site safety philosophy,

- Identifies management roles and responsibilities,

- Defines core safety management processes,

- Identifies LLNL institutional requirements, and

- Defines the functional areas and facilities accrued by the program and the process for transition of facilities, functional areas, and/or systems from construction to activation.

Anyone willfully or thoughtlessly disregarding standards will be subject to immediate removal from the site. Thorough job planning will help ensure that these standards are met.

\section{Safety and Health Policy for the National Ignition Facility during Construction}

Environment, safety and health $(\mathrm{ES} \& \mathrm{H})$ are priority considerations in the planning and execution of work related to the NIF Project at the Lawrence Livermore National Laboratory (LLNL). The management of the NIF Project is committed to providing a safe work environment for all NIF workers and to protecting the public from hazards associated with the construction and operation of the NIF. All work related to NIF construction and parallel operations during the construction period will be performed in a manner that protects the safety of the individual worker, preserves the quality of the environment, and prevents property damage.

This policy is applicable to all workers including LLNL, non-LLNL, and contractor/subcontractor employees working at the NIF Project site. The NIF Project site includes the NIF construction area and support areas shown in Appendix B.

All visitors to the NIF Project Site shall be controlled through implementation of the NIF Site Tour Procedure (see NIF Procedure 5.7, NIF Site Tours).

\section{Environment, safety, and health policy statements specific to NIF:}

- Incidents, whether personal injury or other loss, are unacceptable. 
- Line management is responsible for safety at the NIF construction site.

- Line management, supported by the safety team, will provide consistent guidance and enforcement of a single construction safety program that uniformly governs the activities of all workers at the site.

- Workers will be involved in the work planning process, including the identification of hazards and controls.

- Each worker is directly responsible for ensuring his or her own safety, and for creating a safe work environment.

- Working safely is a condition of employment and disciplinary action policies for violations of safety rules will be enforced by line management.

- A strong program of independent audit, self-assessment, and surveillance will review the effectiveness of the construction safety program.

- Any incident that results in personnel injury or illness, damage to buildings or equipment, or impact to the environment, or is considered a significant near-miss will be investigated by line management.

This CSP for the NIF sets forth the responsibilities, guidelines, rules, policies, and regulations for all workers involved in the construction, equipment and infrastructure installation, acceptance testing, and start-up during the construction period of the NIF. During this period, all workers are required to implement measures to create a universal awareness that promotes safe practice at the work site and will achieve NIF management objectives in preventing accidents and illnesses. This CSP, supported by the Beampath Infrastructure System Integration Management and Installation (BIS IMI) National Ignition Facility Infrastructure Health and Safety Plan is a comprehensive safety program that applies uniformly to all NIF workers on the NIF site.

The NIF Project will comply with all applicable safety, health, and environmental laws, regulations, and requirements, as developed through a Work Smart Standards process.

It is the Project's policy to integrate safety into all aspects of work performed. This approach is based on the seven guiding principles of Integrated Safety Management (ISM) contained in DOE P 450.4 Safety Management System Policy.

ISM is practiced in the execution of all activities associated with the NIF Project. The seven Principles of ISM are:

- Line management is responsible for safety.

- Clear roles and responsibilities are established and maintained.

- Personnel possess competence commensurate with responsibilities.

- Resource allocations are balanced, making ES\&H a priority in project planning and execution. 
- Safety requirements are identified and implemented.

- Hazard controls are tailored to the project work.

- Work activities are authorized before they begin.

The following five Core Functions are used to implement ISM:

- Define scope of work.

- Analyze hazards.

- Develop and implement controls.

- Perform work.

- Feedback and improve.

Successful application of the Principles of ISM is predicated on the proper implementation of the Core Functions when evaluating and controlling all activities. The CSP identifies how and where the Principles and Core Functions are to be implemented. Appendix C shows which specific sections of the CSP implement various aspects of ISM. NIF Project Control Policy 1.11 contains an attachment that lists other NIF Project documents that address the components of ISM. 


\section{Organization and Line Management Responsibilities}

Line management is responsible for safety at the NIF Project site. It is also the responsibility of all workers to perform work safely and in accordance with the CSP. Workers at the site are accountable for their own safety and the safety of others who could be impacted by their activities. Organizations and workers performing supervisory roles have specified responsibilities for carrying out safety-related activities. Workers who perform supervisory functions have increased safety obligations. Management and supervisory workers may delegate safety authority to others in their line organizations; however, the accountability for safety performance and assurance is not transferable.

Line management, supported by the safety team, will provide consistent guidance and enforcement of a single construction safety program that uniformly governs the activities of all workers (LLNL and Contractor) at the site.

This section describes the line management organization responsibilities and interfaces regarding ES\&H at the NIF Project Site. The responsibility definitions are consistent with the NIF Project Execution Plan. Safety Assurance Coordinators, Safety Mangers, and Safety Professionals support the line management organization. The responsibilities identified below focus on the safety-related responsibilities of the individual(s), organization, or firm during the construction of the NIF. The individual(s), organization, or firm may have additional responsibilities that are unrelated to safety during construction of the NIF. 


\section{II.A Line Management}

\section{II.A.1 NIF Project Manager}

The NIF Project Manager, supported by NIF Project line management and staff, has the overall authority and responsibility for the execution of the NIF Project.

The Project Manager will:

- Conduct NIF Project work in accordance with the applicable federal and state regulations, Department of Energy (DOE) Orders, and institutional standards, requirements, and procedures, as they pertain to ES\&H issues.

- Ensure that environmental, safety, radiation protection, quality assurance, and security programs are established and maintained to meet applicable federal, state, and local regulatory requirements.

- Plan and implement the facility construction, equipment procurement, and installation including the evaluation of the hazards involved working through the Associate Project Managers.

- Delegate responsibility to the Beampath Infrastructure Systems (BIS) Associate Project Manager for controlling access to the site and the implementation of NIF Construction Safety Program.

- Provide adequate funding and personnel resources for administering the CSP for the NIF.

- Approve the CSP for the NIF.

\section{II.A.2 Associate Project Managers (APMs)}

The NIF Project has APMs for the following areas: Beampath Infrastructure Systems, Injection Laser System, Amplifier System, Final Optics System, Beam Transport/ Diagnostics Systems, Integrated Computer Controls, and Target Experimental Systems. The APMs are line managers, each responsible for carrying out a major Project activity. They report to the NIF Project Manager. With respect to the work conducted at the NIF Project site or other areas covered by this CSP (see Appendix B), refer to NIF Project Procedure 5.12, NIF Construction Site Work Authorization.

The APMs will:

- Ensure that all NIF workers under their authority perform work in accordance with this Construction Safety Program for NIF.

- Be a member of the Site Management Team when they have work at the site. 


\section{II.A.2.1 Beampath Infrastructure System Associate Project Manager}

The BIS APM is the line manager responsible for the conventional facility and beampath infrastructure (spatial filter vessels, target chamber, utilities, etc.) systems and has added contractual and ES\&H responsibility for areas covered by this CSP (see Appendix B). The BIS APM reports to the NIF Project Manager and for ES\&H will:

- Chair the Site Management Team.

- Lead the development and implementation of the NIF Construction Safety Program.

- Control requirements for access to the site. This includes safety and training requirements.

- Assume Project lead for the direct reporting chain for site incidents (including near misses) to the Institution and the DOE.

- Contract, manage, and direct the Conventional Facilities (CF) Construction Manager, the construction subcontractors, and the IMI Contractor, acting as the University Contracting Officer's Technical Representative.

- Control access to the construction site (including work authorization) and administer the rules and regulations that must be adhered to by anyone working on the site.

- Concur in the CSP and include it in all BIS contracts.

- Ensure the implementation of the NIF Construction Safety Program.

\section{II.A.2.1.1 Beampath Infrastructure System Construction Manager}

The BIS Construction Manager is responsible to be the direct interface with the IMI subcontractor. The BIS Construction Manager reports to the BIS Associate Project Manager and is responsible for the day-to-day management of the construction activities on the NIF site and to implement the responsibilities on behalf of the BIS APM. For ES\&H, the BIS Construction Manager will:

- Act as the direct day-to-day interface with the BIS IMI Construction Management Program Manager and General IMI Construction Manager on all ES\&H issues.

- Ensure that all contractors, subcontractors, and others implement the CSP on the site.

- Develop the CSP and ensure that subtier safety plans are consistent with CSP requirements

- Review and concur in the NIF Infrastructure Health and Safety Plan.

- Be a member of the Site Management Team. 


\section{II.A.2.1.2 Beampath Infrastructure System Commissioning and Operations Manager}

The BIS Commissioning and Operations Manager is responsible for the direct interface for LLNL institutional work activities on the NIF site. The BIS Commissioning and Operations Manager reports to the BIS Associate Project Manager and is responsible for the day-to-day management of external work authorization process on the NIF site and for associated ES\&H implementation. Responsibilities specifically include:

- Act as the direct day-to-day interface with extramural work activities on the NIF site through the NIF Site Work Authorization Program.

- Serve as NIF Facility Point of Contact.

- Ensure that the CSP is implemented for all LLNL institutional employees.

- Be a member of the Site Management Team.

\section{II.A.2.1.2.1 BIS Commissioning and Operations Area Managers}

BIS Commissioning and Operations AMs are BIS Commissioning and Operations line mangers responsible for controlling their activities within their assigned area. During construction, they coordinate with the associated AM for Construction and are responsible for managing and supervising work conducted under the NIF Construction Site Work Authorization Program (see NIF Project Procedure 5.12, NIF Construction Site Work Authorization Procedure). BIS Commissioning and Operations AMs are appointed by the BIS Commissioning and Operations Manager, in this role, they are responsible for the implementation requirements of the NIF CSP and the NIF Infrastructure Health and Safety Plan are carried out.

After turnover from construction to operations, the BIS Commissioning and Operations AM is responsible for authority to control all work within their assigned area during the BIS Commissioning and Operations phase. They report to the BIS Commissioning and Operations Manager and for ES\& H will:

- Ensure that the health and safety procedures set forth in the CSP and the NIF Infrastructure Health and Safety Plan are carried out.

- Ensure that the commissioning and operations activities are planned, hazards evaluated, and effort coordinated through the Job Hazard Analysis (JHA) procedure.

- Be responsible for control of safety in their assigned area and monitor compliance to the Safe Plan of Action (SPA) Procedure.

- Be responsible for area emergency planning within the overall NIF Emergency Plan. 
- Approve Work Authorization for all NIF Project APM activities (other than those of the BIS APM) within the area, and after turnover to Commissioning and Operations Phase, the approval of all work in the area.

- Be responsible for compliance with environmental requirements.

- Be responsible for, within the overall NIF schedule, coordination of work priority in the area.

- Be responsible for definition of and control of interfaces between areas with the other BIS Commissioning and Operations AMs and the AMs for Construction.

\section{II.A.2.1.3 Beampath Infrastructure System Production Manager, Area Manager for Construction for NIF Staging Areas}

BIS Production Manager is responsible for the production activities on the BIS Government Furnished Equipment (GFE) pre-assembly work. The BIS Production Manager reports to the BIS APM and is the line manager responsible for BIS production. The BIS Production Manager is the Area Manager (AM) for Construction for NIF Staging areas. The BIS Production Manager, AM for NIF Staging Areas, has the authority to control all work within the assigned area during the construction phase and for ES\&H will:

- Ensure that the health and safety procedures set forth in the CSP and the NIF Infrastructure Health and Safety Plan are carried out.

- Ensure that the construction activities are planned, hazards evaluated, and effort coordinated through use of JHA Procedures.

- Be responsible for control of safety in their assigned area and monitor compliance to SPA Procedure

- Be responsible for area emergency planning within the overall NIF Emergency Plan.

- Approve Work Authorization for all activities within the area.

- Be responsible for compliance with environmental requirements.

- Be responsible for, within the overall NIF construction schedule, coordination of work priority in the area.

- Be responsible for definition of and control of interfaces between areas with the other Area Managers and BIS Commissioning and Operations Area Managers

\section{II.A.3 BIS IMI Construction Management Program Manager}

The BIS IMI Construction Management (CM) Program Manager is the top ranking subcontractor Line Manager at the NIF Site. The BIS IMI CM Program Manager is responsible for the construction management of both the $\mathrm{CF}$ and the implementation of 
the Integration Management and Installation contract. He reports to the CM Company Corporate Headquarters and for ES\&H will:

- Approve the NIF Infrastructure Health and Safety Plan and ensure that there are adequate resources to support the Plan.

- Be responsible for the overall implementation of the NIF Infrastructure Health and Safety Plan.

- Implement the requirements of the Construction Safety Program for NIF.

\section{II.A.3.1 General IMI Construction Manager}

The General IMI Construction Manager shall manage the occupational safety and health of the NIF Project Site through AMs. The position reports to the BIS IMI CM Program Manager and will:

- Monitor the construction safety activities of the NIF Site and ensure the implementation of the CSP and the NIF Infrastructure Health and Safety Plan.

- Establish an Injury Management Plan.

- Verify that all the contractors/subcontractors and LLNL organizations work in accordance with the NIF Infrastructure Health and Safety Plan requirements.

- Verify that all worker safety education and orientation requirements are met.

- Review the results of the audits for compliance, for recommendations made for correction and prevention of recurrence, and for follow-up measures taken to develop compliance.

- Verify that the following safety requirements are met for contractors / subcontractors:

- Implementation of the site Substance and Alcohol Abuse Prevention Program.

- Work activities are preplanned to identify and control any safety and health issues that may pose a hazard to workers or others.

- Specific job safety training is completed.

- Investigation of all injuries, accidents, and incidents are conducted.

- Safety inspections with CF and BIS contractors/subcontractors are reviewed.

- JHAs and daily SPAs are performed.

- Contractor/subcontractor safety records and performance audits are conducted.

- Contractor/subcontractor safety plans for CF are reviewed for adequacy prior to contractor/subcontractor mobilization.

- Develop safe work recognition and disciplinary programs. 
- Implement the requirements of the Construction Safety Program.

\section{II.A.3.1.1 Area Manager for Construction}

AMs for Construction are each members of line management. AMs have the authority to control all work within their assigned area during the construction phase. They report to the General IMI Construction Manager and for ES\&H will:

- Ensure that the health and safety procedures set forth in the CSP and the NIF Infrastructure Health and Safety Plan are carried out.

- Ensure that the construction activities are planned, hazards evaluated, and effort coordinated through use of JHA Procedures.

- Be responsible for control of safety in their assigned area and monitor compliance to SPA Procedure.

- Be responsible for area emergency planning within the overall NIF Emergency Plan.

- Authorize Work within the area.

- Be responsible for compliance with environmental requirements.

- Be responsible for, within the overall NIF construction schedule, coordination of work priority in the area.

- Be responsible for definition of and control of interfaces between areas with the other Area Managers and BIS Commissioning and Operations Area Managers.

\section{II.A.4 Subcontractor/Sub-Subcontractor Project Manager}

The Subcontractor/Sub-subcontractor Project Manager is the top ranking line manager for the individual contracting firm at the NIF Site. He/she is responsible for the management of the scope of work for their firm's contract. He/she reports to their firm's corporate headquarters and for ES\&H for their firm's scope of work, will:

- Monitor the construction safety activities and ensure the implementation of the CSP and the NIF Infrastructure Health and Safety Plan are carried out.

- Establish an Injury Management Plan.

- Verify that all worker safety education and orientation requirements are met.

- Review the results of the audits for compliance, for recommendations made for correction and prevention of recurrence, and for follow-up measures taken to develop compliance.

- Verify that the safety requirements are met for his/her firm and his firm's subcontractors: 
- Implementation of the site Substance and Alcohol Abuse Prevention Program is carried out.

- Work activities are preplanned using the JHA Procedure and the SPA Procedure to identify and control any safety and health issues that may pose a hazard to workers or others (see NIF Procedures 5.9 and 5.10).

- Specific job safety training is completed.

- Investigation of all injuries, accidents, and incidents are conducted.

- Safety inspections with CF and BIS contractors/subcontractors are reviewed.

- Contractor/subcontractor safety records and performance audits are conducted.

- Contractor/subcontractor safety plans are reviewed for adequacy prior to contractor/subcontractor mobilization.

- Develop safe work recognition and disciplinary programs.

\section{II.B Safety Assurance}

\section{II.B.1 NIF Assurance Manager}

The NIF Assurance Manager is the support manager responsible for the oversight of ES\&H and quality aspects of the NIF Project. He/she reports directly to the NIF Project Manager and for ES\&H will:

- Concur on the content of the CSP for the NIF and provide safety support.

- Perform safety analyses of NIF construction and operation: Preliminary Hazards Analysis (PHA), Preliminary Safety Analysis Report (PSAR), and Final Safety Analysis Report (FSAR) with Operational Safety Requirements (OSRs).

- Obtain the National Environmental Policy Act (NEPA) determination and the environmental permits. Ensure that the requirements of the permits are met.

- Prepare and ensure implementation of the ES\&H Management Plan.

- Participate on the Site Management team and lead the Environmental and Safety Working Group to review Project ES\&H issues.

- Provide monitoring that all applicable federal, state, and local ES\&H regulations are followed.

- Interface with the DOE ES\&H Manager and NIF Programs Assurance Office.

- Oversee the NIF Occurrence and Incident Reporting Program for construction.

- Coordinate with the BIS Safety manager to assure that appropriate work smart standards are in place. 


\section{II.B.1.1 NIF Safety Assurance Coordinator}

The NIF Safety Assurance Coordinator reports to the NIF Assurance Manager and will:

- Assist the Associate Project Manager with the coordination of concurrent construction site work activities related to ES\&H among the NIF elements.

- Act as an interface among NIF elements on ES\&H issues pertaining to the construction site work activities.

- Assist in resolution of any interference related to ES\&H issues among NIF elements.

- Make final determination on issues of conflict (pertaining to ES\&H) among NIF elements.

- Request and coordinate support of the Hazards Control ES\&H Team 2 to resolve specific safety and environmental issues.

- Oversee compliance with environmental permits and the Waste Minimization/Pollution Prevention Plan the Mitigation Action Plan, Programmatic Environmental Impact Statement, etc.

- Act as the interface with DOE and other LLNL programs and directorates on ES\&H issues pertaining to the NIF Project and the construction site activities.

- Track ES\&H deficiencies and status of resolution during construction of the NIF.

- Review safety plans of primary contractors/subcontractors to ensure such plans are consistent with LLNL policies, the NIF CSP, and the NIF Facilities requirements.

\section{II.B.2 BIS Safety Manager}

The BIS Safety Manager reports to the BIS APM and advises the BIS APM and BIS Construction Manager on all coordination and implementation of the CSP and NIF Project specific safety and health policies. This individual is the primary responsible party within the BIS organization for assuring compliance with the CSP and the applicable federal, state, and local rules and regulations as well as integration of DOE and LLNL safety issues into the BIS Safety program. The BIS Safety Manager will:

- Assist the Associate Project Manager with the coordination of concurrent construction site work activities related to ES\&H among the BIS elements.

- Act as an interface among NIF elements on ES\&H issues pertaining to the BIS construction site work activities.

- Assist in resolution of any interference's related to ES\&H issues among BIS elements. 
- Make final recommendations on issues of conflict (pertaining to ES\&H) among BIS elements.

- Assure orientation of all entrants to the NIF Project site in proper safety procedures.

- Develop and implement the safe work recognition and disciplinary programs.

- Be a member of the Site Management Team; be responsible for coordinating and documenting team meetings.

- Support the NIF Assurance Manager in development of the appropriate work smart standards.

\section{II.B.3 BIS IMI Project Safety Manager}

The Project Safety Manager advises the BIS IMI CM Program Manager on coordination and implementation of the CSP and site specific safety and health policies for CF and IMI activities. This individual is responsible for assuring of compliance with the applicable federal, state, and local rules and regulations as well as the company and client regulations and requirements. The BIS IMI Project Safety Manager reports to the BIS IMI CM Program Manager. The BIS IMI Project Safety Manager will:

- Analyze the site-specific safety and health procedures for adequacy.

- Assure adequacy of necessary personal protective equipment selected for employee use.

- Assure orientation of site management regarding policies and procedures, their responsibilities and compliance.

- Develop and ensure orientation of all Contractor employees with the site safety rules and requirements.

- Develop and provide the 10-hour Occupational Safety and Health Administration (OSHA) Construction Safety class for work supervisors.

- Assure compliance with all applicable safety and health procedures through site inspections, documenting such with recommendations to site management and immediate corrective action on "Imminent Danger" situations, (IDLH).

- Assure adequate investigations and analysis on all accidents, (noninjury and injury).

- Assure prompt and adequate medical treatment for construction employees.

- Provide safety and health information for the education of site management and employees to include:

1. Safe work procedures

2. Incident analysis (results, causes, and corrective action) 
3. Inspection results analysis

4. Trend analysis

- Ensure preparation and submittal of required safety and health reports for record-keeping information.

\section{II.B.4 Site Safety Representatives}

The Site Safety Representatives are members of the Site Safety Team and report to the BIS Safety Manager or the BIS IMI Project Safety Manager. These individuals have the responsibility to advise Site Management on implementation of the CSP, the NIF Infrastructure Health and Safety Plan, and safety and health policies and procedures. In addition, these individuals assure compliance with applicable federal, state, local, and LLNL safety and health regulations. The Site Safety Representatives are generally assigned to work with and advise AMs for Construction and BIS Commissioning and Operations Ams, and will:

- Assure adequacy of necessary personal protective equipment selected for employee use.

- Assure orientation of site employees.

- Assure compliance with all appropriate safety and health procedures through regular site inspection, documenting such with recommendations to management and immediate action on imminent danger situations.

- Support adequate investigation and analysis of incidents (noninjury and injury).

- Ensure prompt and adequate treatment for injured employees.

- Provide safety and health training information for management, dupervision, and employees.

- Assure preparation and submittal of required safety and health record-keeping information.

- Assure documentation of required safety and health record-keeping information (i.e., inspections, training, first aid logs, OSHA logs, etc.).

\section{II.B.5 LLNL Environment, Safety, and Health Support}

\section{II.B.5.1 ES\&H Team 2}

ES\&H Team 2, a division in the LLNL Hazards Control Department (HCD), is a key interface between the NIF Project and the LLNL ES\&H support organizations. This team provides technical, advisory, and oversight ES\&H support to the NIF Project and NIF Assurances. The Division Leader for ES\&H Team 2 is a member of the NIF Environment and Safety Working Group and will concur with this CSP for the NIF. 
Specifically, ES\&H Team 2 will:

- Review safety-related materials and submittals from the NIF Project including construction designs and specifications.

- Review Construction Safety Plans submitted by primary contractors/ subcontractors for NIF Assurances.

- Periodically audit the NIF Project safety performance and compliance with the requirements of the CSP at the request of the NIF Assurances Office.

- Perform injury/illness incident record keeping and trending for the NIF Assurance Office and Laboratory management.

- Participate during the Management Prestart Review process and assume the safety support for LLNL workers when an area is transferred from the Area Manager for Construction to the Area Manager for Commissioning and Operations.

- Review Integration Work Sheets (IWSs), which cover LLNL workers working at the NIF site, and for this work, perform the same duties as a site safety representative, with the exception of to whom they report.

- Provide support to the Incident Investigation process at the request of the NIF Project.

- Respond to emergencies at the NIF site if requested by the on-scene Incident Commander (Fire Department) or the NIF Project Office.

- Provide ES\&H review of the purchase of LLNL contracted services under the LLNL ISM process.

- Assist in the preparation of written safety procedures, e.g., IWSs, JHAs, SPAs, and Facility Authorization Basis documents.

\section{II.B.5.2 Emergency Management Division}

HCD, through its Emergency Management Division (EMD) manages the LLNL Fire Department.

The Fire Department will:

- Respond to fire, medical, and hazardous material incidents.

- Provide basic and advanced life support emergency care and emergency medical transport for injuries or illnesses on the NIF Project site.

- Issue burn permits (Hot Work Permits). This responsibility may be delegated to the ES\&H Team 2 Fire Protection Engineer.

- Approve all fire safety system (sprinkler, fire, water, or alarm) outages. 
- Inspect the NIF site to insure compliance with the LLNL fire protection program, including proper emergency vehicle access.

\section{II.C NIF Workers}

NIF workers include LLNL, non-LLNL, and contractor/subcontractor employees working at the NIF Project site. Non-LLNL employees are visitors, students, participating guests, employees matrixed (or on assignment) from other National Laboratories, contract labor, supplemental labor and vendors, including those working for facility operations contractors. NIF workers will:

- Know and understand the ES\&H requirements of their assignments including ISM potential hazards in the work area.

- Perform work assignments in full compliance with guidelines, this CSP for the NIF Project, and the BIS IMI NIF Infrastructure Health and Safety Plan, and their employer's ES\&H requirements.

- Receive appropriate ES\&H training, or equivalent, or shall be escorted and supervised by personnel knowledgeable in the hazards to which they may be exposed.

- Immediately correct or inform the responsible work supervisor of any ES\&Hrelated problems.

- Report all work-related injuries, illnesses, and near-miss incidents to their immediate work supervisor and and to NIF Project Management following the reporting procedure in NIF Procedure 5.11, NIF Construction Site Incident Investigation.

\section{II.D Site Management Team}

The Site Management Team is an advisory panel to the BIS APM. Team Members include the other appropriate APMs, depending on the work being done at the site, the BIS Construction Manager, the BIS Commissioning and Operations Manager, the NIF Assurance Manager, and individuals from NIF Directorate, Hazards Control, and the Department of Energy, as required. The Team's purpose is to address management implementation issues associated with areas covered by this CSP (see Appendix B), including:

- Development and implementation of core management processes for integrating safety into work planning and execution at the NIF site.

- As appropriate, develop/modify site management processes according to work at the site. 
- Address management and leadership issues associated with individual work elements.

- Identify employee training and site access requirements.

- Develop inspection, surveillance, monitoring, reporting, and audit functions and processes.

- Review and, as appropriate, advise the BIS APM on recommended modifications to this CSP and the NIF Infrastructure Health and Safety Plan. 


\section{Core Safety Management Processes}

The purpose of this chapter is to provide specific expectations with respect to safety management of work activities. THE FUNDAMENTAL ASSUMPTION IS THAT ALL INCIDENTS CAN BE PREVENTED!

Core safety management processes are the essential management activities that shall be used to control work safety and reliability. These activities focus on the following operational aspects of safety management:

- Setting expectations and monitoring work.

- Work planning, work authorization, and providing feedback (incident investigation, lessons learned, etc.).

It is line management's responsibility to implement and monitor these core processes and ensure their efficiency through continuous improvement.

\section{III.A Setting Management Expectations and Monitoring Work}

It is management's responsibility to establish how work is conducted and monitored on the NIF construction project. The purpose of these management processes is to align senior management expectations and the performance of mid-level managers, supervisors, and workers.

\section{III.A.1 Contractor Pre-Qualification and Post-Evaluation Process}

Contractors will be selected based on past documented performance indicators consistent with expectations of this CSP. Contractors not demonstrating exceptional past performance in safety will not be invited to participate in BIS Construction. A copy of the CSP and NIF Infrastructure Health and Safety Plan will be provided to all contractors and subcontractors prior to the placing of their bids. Any exceptions taken to the implementation of processes and procedures in either the CSP or the NIF Infrastructure Health and Safety Plan will be submitted in writing and all issues will be resolved, prior to the execution of a contract with those firms and prior to their personnel entering the NIF Project Site.

\section{III.A.2 Safety Rewards Process}

The NIF Project has a formal, personnel recognition program that is used to acknowledge exceptional safety initiatives and actions of NIF workers. The construction contractors will maintain a reward program for their employees and 
subcontractors based on prior submittal and approval of the program, which demonstrates positive incentives for safety performance. Details are provided in the NIF Infrastructure Health and Safety Plan.

\section{III.A.3 Safety Discipline Process}

Anyone violating site safety rules will be subject to discipline. A construction contractor's safety discipline program shall be described in the NIF Infrastructure Health and Safety Plan and all NIF workers on site will be governed by that program.

\section{III.A.4 Site Orientation Safety Training}

A site orientation safety training course will be developed, managed, and delivered by BIS IMI construction management personnel. The purpose of the training shall be to provide an overview of the NIF site, general hazards, access control procedures, and basic roles and responsibilities. This is the initial step in the site access process for all personnel performing work activity on the NIF Project Site. Each contractor/ subcontractor will provide an additional orientation for all newly hired or rehired employees.

\section{III.A.5 NIF Conduct of Operations and Safety Management Training}

The purpose of the training is to inform all BIS Construction, BIS IMI Construction Management, subcontractor, and NIF APM project line managers whose employees perform work on the NIF Project Site of the following:

- NIF Safety Management Culture.

- Integrated "Owner Team" Responsibilities.

- Walkabout Process.

- JHA, SPA, Safety Observation Report, and other Safety Management processes.

The course is a line management course that shall be delivered in part by BIS Construction line managers.

\section{III.A.6 Walkabout Process for Evaluating Safety Implementation}

All levels of line management, supported by safety personnel, regularly viewing site work will perform walkabouts. The purpose of the walkabout is to:

- Assess management and work execution against the requirements of this CSP and the NIF Infrastructure Health and Safety Plan at the construction site.

- Identify and correct the problems that hinder the NIF Project from achieving its safety objectives described in the CSP. 
- Evaluate all levels of safety implementation at the site.

The line management safety assessments will be supplemented by independent audits of the Construction Safety Program.

Details of the NIF Walkabout process are provided in the NIF Project Procedure (see NIF Project Procedure 5.13, Layered Line Management Walkabout).

\section{III.B Work Planning and Authorization Process}

Proper work planning and authorization are crucial for achieving safety. Work planning requires (1) developing the scope of work, (2) analyzing the hazards, and (3) developing a plan to mitigate those hazards. Work must be coordinated and authorized before it can proceed and the work area and activity reviewed before the start of each work task. If incidents occur they must be investigated and actions taken to mitigate future occurrence. This process follows the overall safe work practices as outlined in the ISM program.

While each employer is primarily responsible for the safety of his/her worker's safety, the NIF CSP has implemented specific processes that are mandatory for all work activity on the NIF Project site. Procedures have been developed and will be consistently applied for all work on the NIF Project Site. These are discussed in the sections to follow.

\section{III.B.1 Area Management Organizational Structure and Process}

Areas at the NIF Site are defined as being physically isolated within appropriate barriers and controlled access points. Barriers include walls and fencing, and access control may be through doors and/or gates. During the construction phase, the construction management controls these areas. AMs for Construction are responsible for administration of the NIF CSP and NIF Infrastructure Health and Safety Plan for these areas. As construction of facilities and equipment within a given area is complete, a transition of management responsibilities between the AM for Construction and the Commissioning and Operations AM occurs. Elements of this transition include:

BIS Construction: 1. Completion of final acceptance tests and inspections required by the contractor and the submittal of required documentation.

2. Submittal of equipment operational and maintenance procedure.

3. Completion of equipment specific training requirements. 
BIS Commissioning and Operations:

1. Preparation and execution of operational test plans to verify system operation, adequacy of operational procedures and qualification of activation staff.

2. Preparation of required operational and safety plans including, as a minimum, an Integration Work Sheet.

3. Preparation and implementation of personnel training requirements.

4. Implementation of a Permit Procedure to accommodate corrections/changes by Contractors/Subcontractors after initial tests.

In certain instances, if risks to safety and health, and/or cost and schedule are substantial, a Management Prestart Review may be required by the BIS Construction Manager or the BIS Commissioning and Operations Manager. This process is defined in NIF Project Procedure 9.3, Management Prestart Reviews.

\section{III.B.2 Job Hazards Analysis (JHA) Procedure}

The JHA is used to document the process of pre-job safety planning and hazard recognition. The JHA identifies and analyzes the steps of a work activity for hazards and control measures prior to the work being performed.

A Job Hazard Analysis:

- Identifies the tasks that need control.

- Identifies the hazards.

- Establishes the controls.

- Defines specific training prerequisites.

A JHA contains (as a minimum) the sequence of job steps, the potential hazard of each, and the required controls. All groups working on the NIF site including NIF elements, LLNL Plant Maintenance and Operations and their contractors, supplemental labor, labor only contractors, and contractors/ subcontractors and their subtiers are responsible to complete a JHA and receive approval one week prior to performing the operation and or construction activity. A review and acceptance of the JHA by the BIS IMI Construction Manager and the Construction AM or the BIS Commissioning and Operations AM, as required, must be obtained prior to performing any on-site work activity.

Refer to NIF Project Procedure 5.9, Preparation and Use of the Job Hazard Analysis. 


\section{III.B.3 Safe Plan of Action (SPA) Procedure}

The purpose of the SPA is to ensure that all task leaders:

- Plan and review work daily.

- Assess the hazards in the actual work area and develop ways to mitigate those hazards consistent with the IWS/JHA or contract/JHA that authorizes the work.

- Form and identify a team by involving workers in daily work planning and obtaining feedback from all team members.

- Obtain documented team acknowledgement of understanding of hazards and the associated controls.

All groups working on the NIF site are responsible for completing an SPA prior to performing the operation and or construction activity. This process is fully described in the NIF Project Control Manual, Project Procedure 5.10, Safe Plan of Action.

\section{III.B.4 NIF Construction Site Work Authorization Procedure}

The purpose of this procedure is to manage workers who are not directly under BIS Construction contracts and that are assigned and authorized to work in a given area of the NIF Project site. These workers generally require incidental access to the work area. This procedure controls site access and ensures that the work is properly planned, coordinated, and authorized.

Generally this process applies to LLNL and non-LLNL workers and their consultants and subcontractors during the construction phase that are not directly contracted to the BIS IMI Construction Management.

The NIF Construction Site Work Authorization Procedure is fully described in the NIF Project Control Manual, Project Procedure 5.12. Only Workers approved and authorized by personnel by name on the Work Authorization List will be allowed to perform work activity on the site. The BIS Construction office will maintain the Work Authorization List.

\section{III.B.5 Incident Investigations and Lessons Learned}

The Incident Investigation Procedure provides a basis for a Lessons Learned program so that the NIF Project can learn from any less-than-adequate management or work performance.

Incidents include personal injury, equipment damage, and near misses. The analysis of incidents shall be considered a line manager function. All incidents shall be reported immediately to the BIS IMI Construction Manager and the BIS Construction Manager. 
- Any NIF worker can identify an incident.

- Line Management is responsible for investigating incidents.

- Causes will be identified.

- Lessons Learned will be published.

- Corrective actions will be verified.

Designated line-managers will be trained in the NIF Incident Investigation process. The Site Management Team shall monitor the implementation and manage the incident Investigation process.

This procedure is fully described in the NIF Project Procedure 5.11, NIF Construction Site Incident Investigation. 


\section{LLNL Institutional Requirements}

\section{IV.A LLNL Site Access}

Only authorized personnel are allowed access to laboratory property. The direct line employer of each worker is responsible for assuring each worker complies with requirements of LLNL Site Access. Authorized personnel will receive a badge. This must be shown to the guard at the gate upon entry to the laboratory, and must be worn at all times while on site. The following privately owned items are not permitted on the laboratory site:

- Pepper spray or mace

- Alcoholic beverages

- Illegal or unlawfully possessed controlled substances (drugs)

- Poisons or corrosive materials

- Dangerous weapons

- Explosives

- Binoculars or telescopes

- Cameras

- Any other items prohibited by law.

Once on site, workers are expected to report directly to their work location. Workers will be informed of all site access rules by their employer, including updates or changes in LLNL requirements when they occur.

\section{IV.B Drug Free Work Place Program}

The Contractor/Subcontractor shall adopt and enforce a substance-testing program at no cost to LLNL, which complies with appropriate federal regulations and utilizes a Department of Health and Human Services certified laboratory.

The Contractor/Subcontractor shall also test its employee upon reasonable suspicion of that employee's use of controlled substances, abuse of legal substances, or after that, an employee's involvement in a NIF construction incident, and shall provide the results to the BIS Site Management Team.

LLNL may deny access to the LLNL Sites to any individual who tests positive on a substance screening test. 


\section{IV.C NIF LLNL Safety Requirements}

Applicable environmental, safety and health requirements for NIF Project site work efforts are also additionally included in Appendix A of this CSP.

\section{IV.D Traffic and Vehicles}

Drivers are responsible for operating vehicles in a safe manner and adhering to posted speed limits. Individuals who drive on site must have on their person a valid, current driver's license from their state of residence. They must operate their vehicles in accordance with the California Vehicle Code. The driver must ensure that all occupants of the vehicle wear seat belts. Designated parking locations are provided for vehicles. Pedestrians have the right-of-way at marked crosswalks and unmarked intersections, but vehicles have the right-of-way at all other points on the roadway. LLNL Protective Force division officers can cite operators who violate the on-site traffic and parking regulations.

\section{IV.E Stop-Work Authority and Procedures}

Activities that are imminently dangerous to workers, the public, the environment, or property shall be stopped immediately by any NIF worker. "Stopping work" includes stabilizing an imminent danger situation to the extent that it can be left unattended for a prolonged period of time until the issue is resolved. The person requesting the work stoppage shall notify the manager responsible for the operation. A stop-work order affects only those areas immediately involved in the hazardous situation.

Stop-work orders are normally only issued by the BIS Associate Project Manager, BIS Construction Manager, the BIS IMI Construction Manager, or other cognizant manager. If they are absent and a contractor's/subcontractor's personnel are involved in an imminent-danger situation, all and any worker are authorized to directly contact the personnel and stop the operation. The BIS Construction Manager, other manager, BIS Project Safety Manager, shall then be immediately located and contacted and informed of the stop-work order. Imminently dangerous situations must be mitigated immediately. The stop-work order will be in effect until the contractor/subcontractor resolves the problem(s) and brings the work area(s) to satisfactory conformance with health and safety requirements. Work can restart upon approval by the NIF Project Manager, with concurrence of the NIF Assurance Manager.

A formal Incident Analysis Report may be required after each instance in which work has been stopped (see Project Procedure 5.11, NIF Construction Site Incident Investigation). 


\section{IV.F Permits and Authorizations}

There are several permits and authorizations required on the NIF project. These include permits for hot work, excavations and on-grade slab penetration, penetration of concrete structures (floors, walls, and ceilings), work in confined spaces, work on energized equipment, and air and storm water work. Also included are authorizations for work near energized equipment and crane and hoist operation. NIF workers are responsible for obtaining or assisting with the processing of these permits and authorizations as necessary prior to starting the defined activity. Caution: All required permits and authorizations may not be addressed in this section, and any work activity that presents unusual work conditions impacting ES\&H issues should be brought to the attention of line management. Please refer to CSP, Appendix A, for Permits and Authorizations requirements.

\section{IV.G Incident Notification, Reporting and Investigation}

The timely evaluation of incidents is a valuable component of ISM to provide feedback and improvement to the safety process. It is the policy of the NIF Project to track all incidents and to investigate all incidents related to the construction program that result in personnel injury or illness, damage to buildings or equipment, or impact to the environment, as a result of an incident or natural phenomena. Supervisors and workers are encouraged to report incidents, near misses, and injuries so that corrective action can be taken to prevent recurrence. As a valuable management tool, near misses may also be investigated at the request of the Site Management Team for the prevention of incidents and detecting trends. Near miss incidents are events or a series of events that could have resulted in serious injury or illness or property damage, but did not due to circumstances or changes in events. It is the construction contractor's / subcontractor's obligation to investigate all occurrences, and submit the information to the BIS IMI Construction Manager. Contractors/subcontractors shall cooperate fully with the investigation of occurrences conducted by LLNL, the University of California, or the U.S. DOE.

The data generated from accident/incident investigations shall be analyzed, tracked, and trended by contractors/subcontractors having the accident/incident. The information generated will be used to identify cause, trends of unsafe behavior or conditions, and unacceptable practices. Trend data should be used for the elimination of unsafe conditions, to minimize occurrence or recurrence of injuries, and for employee training. The information generated shall be forwarded to the Construction Manager on a monthly basis.

In the event an injury is or has the possibility of being a fatality, there is serious or fatal injury to a nonemployee, or there are multiple serious injuries or extensive damage 
to any property, in addition to the above notifications, IMMEDIATE notification will be made to the NIF Project Office, the insurance carrier safety consultant, and the insurance broker.

Fatality. In the event an incident results in a fatality on the NIF Project site, the University of California Police Department at LLNL shall take control of the incident scene pending investigation by local authorities (i.e., Alameda County Coroner Office and/or District Attorney, OSHA, DOE) having jurisdiction over occupational fatalities.

Notification. All official notifications to the family of an injured worker will be made by the employer of the injured worker(s).

Contractors/subcontractors and their employees or agents, LLNL employees, and non-LLNL employees are not to discuss with the media any facts, hearsay, or assumptions regarding incidents occurring during the NIF construction project. ALL releases to the news media must be either made by or approved by the University.

Refer to NIF Project Procedure 5.11 for incident reporting and investigation.

\section{IV.G.1 DOE Occurrence Reporting Requirements}

Depending on the severity of the incident the DOE Occurrence notification requirements for which the University/LLNL are contractually obligated to comply with may be triggered. DOE must be notified of an incident within two hours of determining that the occurrence is reportable to them (e.g., severe injury, significant financial loss, and significant near-miss events). As such, immediate notifications through the chain of command are essential so that LLNL's procedures for categorizing and determining if DOE notification is required may occur. Refer to NIF Project Procedure 5.11 for the notification chain. The NIF Assurance Office together with the NIF Programs Assurance Office contact, and in consultation with LLNL ES\&H Team 2 if necessary, will make the determination as to whether or not an incident is reportable to the DOE. DOE Occurrence Reporting may result in a formal investigation of the reported incident by LLNL, DOE, or a combination of the two.

\section{IV.G.2 Injury Reporting and Retention}

Current safety statistics shall be maintained weekly by each contractor/subcontractor. The IMI Construction Manager shall prepare weekly safety statistics, with the above information totaled for the NIF site, and shall make them available for review upon request. A monthly report shall be provided by the IMI Construction Manager to the BIS Construction Manager and shall include weekly and up-to-date totals of hours worked, number of incidents, and number of injuries (in 
accordance with OSHA reporting criteria for injuries or illnesses involving days away from work [lost time], restricted work, medical treatment, and first aid).

All reports pertaining to injury or illness of employees or nonemployees shall be preserved and not destroyed without approval from the Contractor's Safety Representative and NIF Project Management.

Reports will not be released to anyone without approval of the NIF Safety Coordinator and will be kept on file for five years following the date of occurrence.

Injury and Illness records on LLNL employees are covered by the DOE moratorium on the destruction of epidemiological records and will be maintained in accordance with University and Laboratory policies.

\section{IV.H Environmental Requirements}

\section{IV.H.1 National Environmental Policy Act}

The NEPA requires that significant federal construction projects undergo an environmental review of the proposed project. The NIF has undergone such a review of the overall project; however, new smaller activities are reviewed to ensure that they fit within the umbrella of the overall project review.

\section{IV.H.2 Digging}

Anyone who is planning to dig, excavate, or drill into soil must contact the LLNL Environmental Operations Group, ES\&H Team 2 Environmental Analyst, and the LLNL Environmental Restoration Division to determine whether the area has been previously approved for such digging, or, requires a site evaluation for potential buried waste.

\section{IV.H.3 Historical/Archeological Materials}

If historical/archeological materials are encountered in an excavation, all digging in the vicinity of the find shall stop until the Laboratory Archeologist can inspect the materials and approve the resumption of work. Examples of such materials are stone tools, mortars/pestles, shells, bone, human burials, foundation materials, square nails, and glass. Any necessary mitigation measures to protect significant unexpected discoveries will be developed and implemented in conjunction with DOE, the State Historic Preservation Office, and the Advisory Council on Historic Preservation. 


\section{IV.H.4 Hazardous Materials}

Oils, paints, solvents, fuels, and similar chemicals must be stored so that they do not spill onto the ground. If a spill of such material occurs into the environment, the LLNL Environmental Protection Department (EPD) should be notified immediately, so that a cleanup can be initiated. An LLNL Environmental Duty Officer is on call 24 hours/day. Contractors/subcontractors must provide a list of all chemicals, to be brought on site by the contractor, to the BIS IMI Construction Manager who in turn will provide the information to the EPD ChemTrack Group so that the chemicals can be bar-coded for tracking. When a work contract has been completed, there shall be no unauthorized hazardous materials or hazardous waste left behind at the job site. All hazardous wastes must be segregated from municipal trash and managed appropriately according to federal, state, and local regulations and LLNL waste management policies. Additionally, trash from lunch areas, etc., should be discarded in appropriate waste containers. Recyclable materials such as paper, cardboard, and wood must be managed appropriately in recycling bins.

\section{IV.H.5 Air Pollution}

Work should be conducted so that dust generation and odor nuisance is minimized. If there is a potential for such air quality problems, appropriate control measures should be approved by project management in advance of the work. Any portable internal combustion generator greater than a prescribed horsepower (e.g., 50 horsepower) must have an air permit before it is used. Refer also to CSP, Appendix A, Section 33 Permits and Authorizations.

\section{IV.H.6 Endangered Species}

Work should be conducted in a manner consistent with the protection of endangered species on the site. The required protective measures are defined and described by LLNL wildlife biologists and communicated through the BIS APM. The LLNL wildlife biologist must be contacted to initiate a survey for any endangered species that may be impacted by the NIF Project site prior to the start of construction activities in new locations.

\section{IV.H.7 Storm Water Pollution Prevention Plans:}

NIF contractors are required to follow the NIF Storm Water Pollution Prevention Plans (SWPPPs), which are required documents under State Water Resources Control Board Order No. 99-08-DWQ, and National Pollution Discharge Elimination System General Permit No. CAS000002. The SWPPPs are included in the contract bid documents, and a contract specific scope sheet identifies the SWPPP elements within the responsibilities of each individual contract package. Project changes affecting storm 
water that are outside of the scope of these plans or regulation changes could require new pollution prevention practices to be implemented by the Project.

\section{IV.I Emergency Response and Notification}

\section{IV.I.1 Emergency Assistance Procedures}

All calls for emergency assistance, whether they be for medical aid, fire fighting, rescue, etc., will be requested by telephone through the LLNL HCD's EMD Dispatch Center by dialing 911 from an on-site LLNL telephone or 447-6880 from a cellular telephone or other telephone that is not connected to the LLNL telephone exchange (LLIX). Calls to the Dispatch Center are answered by an EMD Dispatcher, who will send fire and/or paramedics units to the emergency at the NIF site. An HCD Health and Safety Technician will also respond to all emergencies called into the Dispatch Center. The Fire Department on-scene Incident Commander has authority to call and direct appropriate LLNL and external resources, including ES\&H Team 2, Health Services Department, EPD, Livermore City/Alameda County fire units to control emergencies on the NIF Project site. The EMD is in charge of the incident scene until the Incident Commander formally transfers control to the ES\&H Team 2 liaison upon stabilization of the scene or termination of activities. Depending on the size and extent of the emergency, control of the scene may be transferred to an environmental analyst, if environmental cleanup is required, or returned to the BIS APM if the ES\&H Team 2 considers the area safe.

Release of the incident scene will occur only after the ES\&H Team 2 has completed a preliminary investigation to determine the cause of the incident and the LLNL management responsible for the activity, facility, or program has reached a decision on the need for a more formal investigation (e.g., incident analyses).

Incident notification and investigation shall be carried out concurrently in accordance with NIF Project Procedure 5.11, NIF Construction Site Incident Investigation.

\section{IV.I.2 Medical Services and First Aid}

Employers on construction sites are required by OSHA to insure the availability of medical personnel for advice and consultation on matters of occupational health. On a 24-hour basis, EMD is available to dispatch paramedics to seriously injured individuals on the NIF Project site and will arrange to transport injured individuals to appropriate medical treatment facilities-either on or off of the LLNL site. 
The NIF Project contractors/subcontractors do not use LLNL's Health Services Department for first aid. NIF Project first aid will be provided through use of a BIS IMI Emergency Medical Technician at the Safety Orientation Trailer or through prearranged appropriate medical treatment facilities on site as described in the NIF Infrastructure Health and Safety Plan are carried out. LLNL employees will be treated at HSD.

\section{IV.J Disaster Response}

\section{IV.J.1 Self-Help Planning}

LLNL realizes that during a major emergency, such as an earthquake, external help may not be immediately available. Therefore, the philosophy of emergency preparedness at LLNL relies upon the resources of individual organizations on-site to protect the welfare of workers, this program is known as the "Self-Help Program" (SHP).

For the construction, equipment and infrastructure installation, acceptance testing, and start-up of NIF during the construction period, the BIS IMI Construction Manager is responsible for preparing and maintaining a SHP plan to address the impact that major LLNL emergency situations would have on the NIF Project site. The BIS IMI Construction Manger shall consult with both the NIF Program and LLNL self-help Managers on the development of this plan. The plan at a minimum shall provide for:

- Accounting of personnel working on the NIF site.

- Maintaining the safety and well being of personnel on the NIF site.

- First-aid response in the absence of assistance from LLNL resources.

- Locating and rescuing trapped or injured personnel.

- Locating and reporting obvious damage to facilities.

- Control of personnel on the NIF site until LLNL site evacuation plans have been coordinated by the LLNL Emergency Management Center and external local law enforcement authorities (e.g., California Highway Patrol, Livermore Police).

The BIS IMI Construction Manager will designate an Assembly Point Leader (APL) for the NIF Project site, who will be responsible for assuring compliance to LLNL Emergency Programs and providing contractor/subcontractor notification, understanding, and training for the disaster and emergency programs on the NIF Project Site. Upon activation of the SHP the APL shall supervise emergency activities on the NIF Project site. APL responsibilities include: accountability, care, and protection of personnel; first aid, transporting the injured, situation assessment and reporting, and protection of facilities within the site; and search and rescue operations by the volunteer re-entry (sweep) teams. The APL will request assistance for the NIF Project site as 
needed. The APL will communicate information (e.g., personnel accountability, injury/damage reports) to the NIF Program Zone Supervisor/Control Point.

\section{IV.J.2 NIF Self-Help Plan - NIF Emergency Procedures}

In the event of an emergency or multiple casualty incident, all NIF Project site employees (on the NIF site, in the construction trailers, and at other NIF associated sites) will cease work immediately and report to the assembly points shown on the assembly point map as developed and maintained by the BIS IMI Construction Manager. If readily accessible, employees will shut down any equipment in their immediate area prior to reporting to their assembly point. Employees reporting to assembly points other than the one at the NIF Project site shall follow the instructions of the Assembly Point Leader for that area.

Employees should use the "buddy" system to assist personnel, perform required first aid, and deliver injured employees to the Triage Center, but should not move severely injured employees. The name and location of these personnel should be reported immediately to the Assembly Point Leader and the Contractor line manager for disposition upon arriving at there designated assembly point.

\section{IV.J.3 Flooding}

The NIF Project site is located above the 100-year flood plain and will not be affected by flood of this magnitude. The main threat from flooding at the NIF Project Site is due to overflow of the Arroyo Las Positas from excessive precipitation (such as that which may occur during a 2000 year flood). Generally, severe flooding from excess precipitation develops relatively slowly. This would allow the opportunity for mitigate actions to be taken, such as securing hazardous material inventories and moving them to safe locations.

Each contractor/subcontractor is responsible for taking appropriate actions for the inventories under their control. BIS IMI Construction Management, and as necessary LLNL emergency management/response personnel, will oversee flood mitigation activities. 


\section{Appendix B}

\section{Areas Covered by the Construction Safety Program}

For the purpose of determining where the requirements of the CSP for the NIF apply, the NIF Project Site includes the laydown and construction support areas listed below. The CSP requirements apply to NIF contractors and subcontractors, LLNL employees and non-LLNL employees, when working in these areas.

\begin{tabular}{|l|l|}
\hline \multicolumn{1}{|c|}{ Main Construction Site } & \multicolumn{1}{c|}{ Staging Areas } \\
\hline $\begin{array}{l}\text { Fenced Site (includes LTAB, OAB, CP, and } \\
\text { trailers' parking area) }\end{array}$ & B431 Highbay \\
\hline 5900 Yard & B298 Laydown \\
\hline Helipad & West Perimeter Road \\
\hline & B493, B494 \\
\hline & T4997, T4998, T4999 \\
\hline
\end{tabular}




\section{ICF/NIF Program Facilities and Construction Laydown Areas}

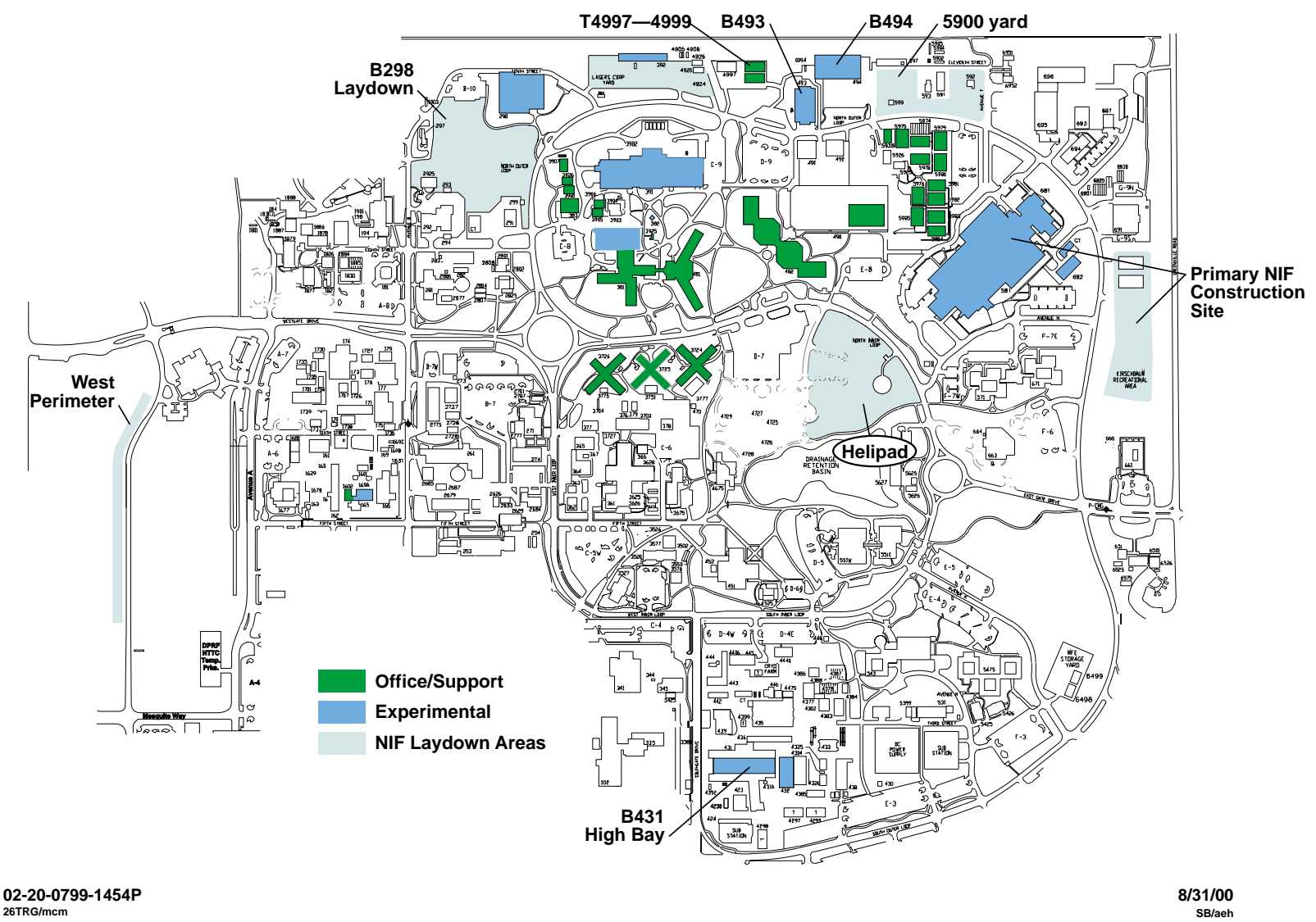

Sections of the Construction Safety Program that Implement the Various Guiding Principles and Core Functions of ISM 


\section{Appendix C}

Sections of the Construction Safety Program that Implement the Various Guiding Principles and Core Functions of ISM

\begin{tabular}{|c|c|c|}
\hline $\begin{array}{l}\text { DOE P 450.1, } \\
\text { Safety } \\
\text { Management } \\
\text { Systems "ISMS" } \\
\text { Element }\end{array}$ & Title & $\begin{array}{l}\text { Applicable Section of this } \\
\text { Construction Safety Program }\end{array}$ \\
\hline $\begin{array}{l}\text { Guiding Principle } \\
1\end{array}$ & $\begin{array}{c}\text { Line Management } \\
\text { Responsibility for } \\
\text { Safety }\end{array}$ & $\begin{array}{l}\text { Chapter II: Organization and Line } \\
\text { Management Responsibilities }\end{array}$ \\
\hline $\begin{array}{l}\text { Guiding Principle } \\
2\end{array}$ & $\begin{array}{l}\text { Clear Roles and } \\
\text { Responsibilities }\end{array}$ & $\begin{array}{l}\text { Chapter II: Organization and Line } \\
\text { Management Responsibilities } \\
\text { Appendix A, Section I: General Rules } \\
\text { and Codes of Safe Practices } \\
\begin{array}{l}\text { Appendix A: Responsibilities (in each } \\
\text { subsection) }\end{array}\end{array}$ \\
\hline $\begin{array}{l}\text { Guiding Principle } \\
3\end{array}$ & $\begin{array}{c}\text { Competence } \\
\text { Commensurate } \\
\text { with } \\
\text { Responsibilities }\end{array}$ & $\begin{array}{l}\text { Section III.A.4: Site Orientation Safety } \\
\text { Training } \\
\text { Section III A.5: NIF Conduct of } \\
\text { Operations and Safety Management } \\
\text { Training } \\
\text { Section III.B.2: Job Hazards Analysis } \\
\text { (JHA) } \\
\text { Project Procedure 5.9: Job Hazards } \\
\text { Analysis } \\
\text { Section IV.G: NIF Integration } \\
\text { Worksheets }\end{array}$ \\
\hline $\begin{array}{l}\text { Guiding Principle } \\
4\end{array}$ & $\begin{array}{l}\text { Balanced } \\
\text { Priorities }\end{array}$ & $\begin{array}{l}\text { Chapter I: Safety and Health Policy } \\
\text { for the National Ignition Facility } \\
\text { during Construction } \\
\text { Section II.A.1: Project Manager } \\
\text { (Responsibilities) } \\
\text { Section III.B: Work Planning and } \\
\text { Authorization Process }\end{array}$ \\
\hline
\end{tabular}




\begin{tabular}{|c|c|c|}
\hline $\begin{array}{l}\text { Guiding Principle } \\
5\end{array}$ & $\begin{array}{l}\text { Identification of } \\
\text { Safety Standards }\end{array}$ & $\begin{array}{l}\text { Section III.B: Work Planning and } \\
\text { Authorization Process }\end{array}$ \\
\hline & $\begin{array}{l}\text { and } \\
\text { Requirements }\end{array}$ & $\begin{array}{l}\text { Section III.B.2: Job Hazards Analysis } \\
\text { (JHA) }\end{array}$ \\
\hline & & $\begin{array}{l}\text { Project Procedure 5.9: Job Hazards } \\
\text { Analysis }\end{array}$ \\
\hline & & $\begin{array}{l}\text { Section III.B.4: Safe Plan of Action } \\
\text { (SPA) }\end{array}$ \\
\hline & & $\begin{array}{l}\text { Project Procedure } 5.10^{*} \text { : Safe Plan of } \\
\text { Action }\end{array}$ \\
\hline & & $\begin{array}{l}\text { Section III B.3: NIF Construction Site } \\
\text { Work Authorization Procedure }\end{array}$ \\
\hline & & $\begin{array}{l}\text { Project Procedure } 5.12: \text { NIF } \\
\text { Construction Site Work Authorization } \\
\text { Procedure }\end{array}$ \\
\hline & & Appendix A \\
\hline & & $\begin{array}{l}\text { Section IV.G: NIF Integration } \\
\text { Worksheets }\end{array}$ \\
\hline $\begin{array}{l}\text { Guiding Principle } \\
6\end{array}$ & $\begin{array}{l}\text { Hazards Control } \\
\text { Tailored to the }\end{array}$ & $\begin{array}{l}\text { Section III.B: Work Planning and } \\
\text { Authorization Process }\end{array}$ \\
\hline & $\begin{array}{l}\text { Work being } \\
\text { Performed }\end{array}$ & $\begin{array}{l}\text { Section III.B.2: Job Hazards Analysis } \\
\text { (JHA) }\end{array}$ \\
\hline & & $\begin{array}{l}\text { Project Procedure 5.9: Job Hazards } \\
\text { Analysis }\end{array}$ \\
\hline & & $\begin{array}{l}\text { Section III.B.4: Safe Plan of Action } \\
\text { (SPA) }\end{array}$ \\
\hline & & $\begin{array}{l}\text { Project Procedure } 5.10^{*} \text { : Safe Plan of } \\
\text { Action }\end{array}$ \\
\hline & & Appendix A \\
\hline & & $\begin{array}{l}\text { Section IV.G: NIF Integration } \\
\text { Worksheets }\end{array}$ \\
\hline
\end{tabular}




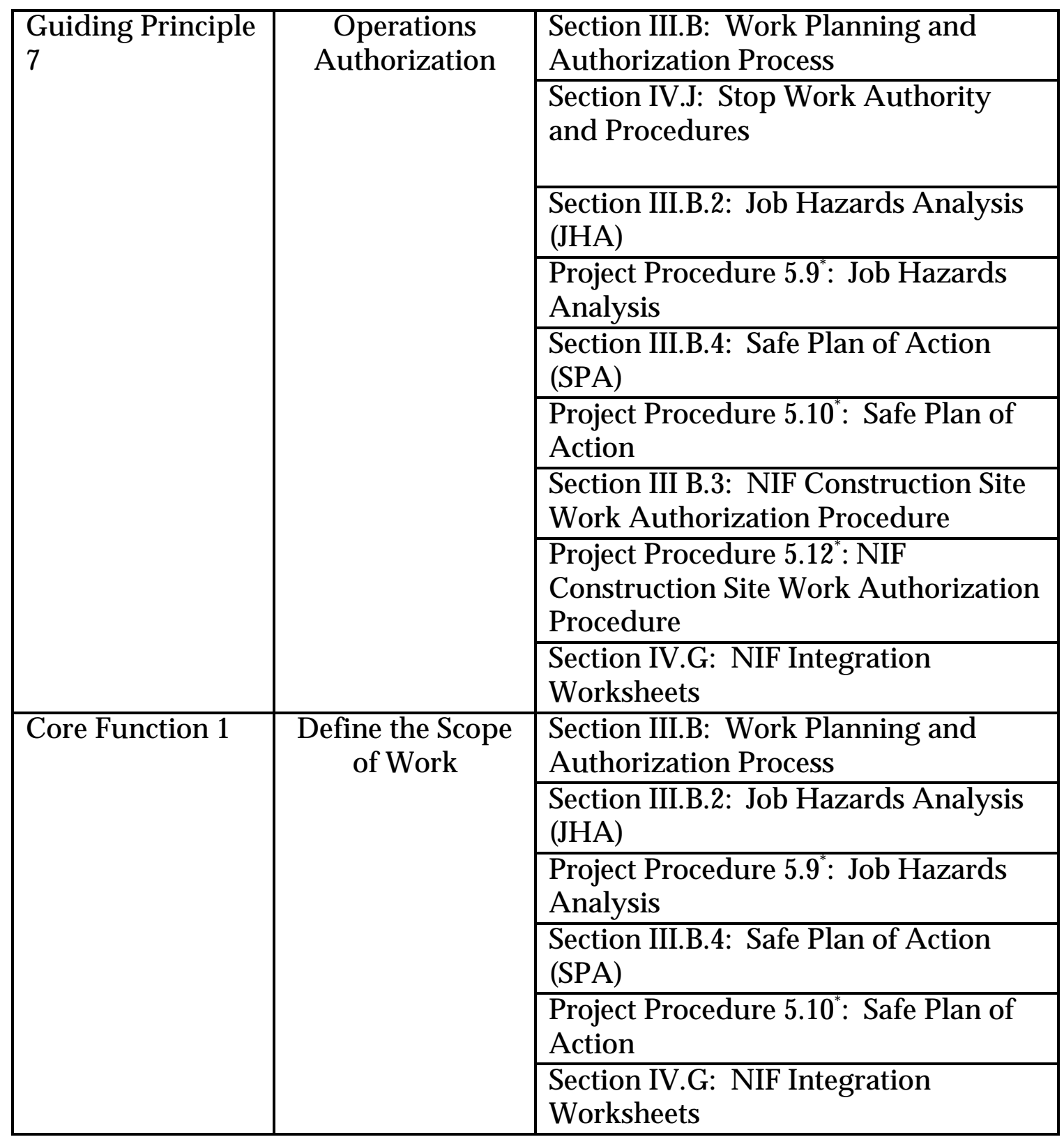




\begin{tabular}{|c|c|c|}
\hline \multirow[t]{5}{*}{ Core Function 2} & \multirow[t]{5}{*}{ Analyze Hazards } & $\begin{array}{l}\text { Section III.B.2: Job Hazards Analysis } \\
\text { (JHA) }\end{array}$ \\
\hline & & $\begin{array}{l}\text { Project Procedure 5.9*: Job Hazards } \\
\text { Analysis }\end{array}$ \\
\hline & & $\begin{array}{l}\text { Section III.B.4: Safe Plan of Action } \\
\text { (SPA) }\end{array}$ \\
\hline & & $\begin{array}{l}\text { Project Procedure 5.10*: Safe Plan of } \\
\text { Action }\end{array}$ \\
\hline & & $\begin{array}{l}\text { Section IV.G: NIF Integration } \\
\text { Worksheets }\end{array}$ \\
\hline \multirow[t]{8}{*}{ Core Function 3} & \multirow{8}{*}{$\begin{array}{l}\text { Develop and } \\
\text { Implement } \\
\text { Controls }\end{array}$} & $\begin{array}{l}\text { Section III.B.2: Job Hazards Analysis } \\
\text { (JHA) }\end{array}$ \\
\hline & & $\begin{array}{l}\text { Project Procedure 5.9*: Job Hazards } \\
\text { Analysis }\end{array}$ \\
\hline & & $\begin{array}{l}\text { Section III.B.4: Safe Plan of Action } \\
\text { (SPA) }\end{array}$ \\
\hline & & $\begin{array}{l}\text { Project Procedure 5.10*: Safe Plan of } \\
\text { Action }\end{array}$ \\
\hline & & $\begin{array}{l}\text { Section III B.3: NIF Construction Site } \\
\text { Work Authorization Procedure }\end{array}$ \\
\hline & & $\begin{array}{l}\text { Project Procedure } 5.12^{*}: \text { NIF } \\
\text { Construction Site Work Authorization } \\
\text { Procedure }\end{array}$ \\
\hline & & $\begin{array}{l}\text { Section IV.G: NIF Integration } \\
\text { Worksheets }\end{array}$ \\
\hline & & Appendix A \\
\hline \multirow[t]{2}{*}{ Core Function 4} & \multirow[t]{2}{*}{ Perform Work } & $\begin{array}{l}\text { Section III.B.4: Safe Plan of Action } \\
\text { (SPA) }\end{array}$ \\
\hline & & $\begin{array}{l}\text { Project Procedure 5.10*: Safe Plan of } \\
\text { Action }\end{array}$ \\
\hline \multirow[t]{4}{*}{ Core Function 5} & \multirow[t]{4}{*}{$\begin{array}{l}\text { Feedback and } \\
\text { Improvement }\end{array}$} & $\begin{array}{l}\text { Section III.A: Setting Management } \\
\text { Expectations, Monitoring Work and } \\
\text { Providing Feedback }\end{array}$ \\
\hline & & $\begin{array}{l}\text { Project Procedure 5.11*: NIF Incident } \\
\text { Analysis Procedure }\end{array}$ \\
\hline & & $\begin{array}{l}\text { Project Procedure 5.13*: Layered Line } \\
\text { Management Walkabout Process }\end{array}$ \\
\hline & & $\begin{array}{l}\text { Section III.B.5: Incident Analysis and } \\
\text { Lessons Learned }\end{array}$ \\
\hline
\end{tabular}

${ }^{*}$ Project Procedures referenced above are based upon the revision in force as of the effective date of this Construction Safety Program. 


\section{List of Acronyms}

$\begin{array}{ll}\text { AM } & \text { Area Manager } \\ \text { ANSI } & \text { American National Standards Institute } \\ \text { APL } & \text { Assembly Point Leader } \\ \text { ARO } & \text { Assembly, Refurbishment and Operation } \\ \text { APM } & \text { Associate Project Manager } \\ \text { BIS } & \text { Beampath Infrastructure System } \\ \text { CAL/OSHA } & \text { California Occupational Safety and Health Administration } \\ \text { CBSC } & \text { California Building Standards Code } \\ \text { CCL } & \text { Control Center Leader } \\ \text { CCR } & \text { California Code of Regulations } \\ \text { CFR } & \text { Code of Federal Regulations } \\ \text { CHP } & \text { California Highway Patrol } \\ \text { CII } & \text { Construction Industry Institute } \\ \text { CM } & \text { Construction Manager } \\ \text { CR } & \text { Contractor Representative } \\ \text { CSO } & \text { Construction Safety Officer } \\ \text { CSP } & \text { Construction Safety Program for the NIF } \\ \text { DAPL } & \text { Deputy Assembly Point Leader } \\ \text { DOE } & \text { Department of Energy } \\ \text { DOT } & \text { Department of Transportation } \\ \text { EMD } & \text { Emergency Management Division (of HCD) } \\ \text { EPA } & \text { Environmental Protection Agency } \\ \text { EPD } & \text { LLNL's Environmental Protection Department } \\ \text { ES\&H } & \text { Environment, Safety, and Health } \\ \text { FHA } & \text { Fire Hazards Analysis } \\ \text { FSAR } & \text { Final Safety Analysis Report } \\ \text { GFCI } & \text { Ground fault circuit interrupter } \\ \text { HCD } & \text { LLNL's Hazards Control Department } \\ \text { HSD } & \text { LLNL's Health Services Department } \\ \text { HWM } & \text { LLNL's Hazardous Waste Management division } \\ \text { ICF } & \text { Inertial Confinement Fusion } \\ \text { IMI } & \text { Integration Management and Installation } \\ \text { ISM } & \text { Integrated Safety Management } \\ \text { IWS } & \text { Integration Work Sheet } \\ \text { JHA } & \text { Job Hazards Analysis } \\ \text { LLNL } & \text { Lawrence Livermore National Laboratory } \\ \text { LRU } & \text { Line Replaceable Unit } \\ \text { LTAB } & \text { Laser and Target Area Building } \\ & \end{array}$




$\begin{array}{ll}\text { MSDS } & \text { Material Safety Data Sheet } \\ \text { NEPA } & \text { National Environmental Policy Act } \\ \text { NFPA } & \text { National Fire Protection Association } \\ \text { NIF } & \text { National Ignition Facility } \\ \text { OAB } & \text { Optics Assembly Building } \\ \text { OCIP } & \text { Owner Controlled Insurance Program } \\ \text { ORR } & \text { Operational Readiness Review } \\ \text { OSHA } & \text { Occupational Safety and Health Administration } \\ \text { OSP } & \text { Operational Safety Plan } \\ \text { OSR } & \text { Operational Safety Requirement } \\ \text { OTP } & \text { Operational Test Procedures } \\ \text { PICS } & \text { Problem Identification \& Correction System } \\ \text { PPE } & \text { Personnel protective equipment } \\ \text { PSAR } & \text { Preliminary Safety Analysis Report } \\ \text { QA } & \text { Quality Assurance } \\ \text { QMC } & \text { Quality Managers of Construction } \\ \text { SAAR } & \text { Supervisor's Accident Analysis Report } \\ \text { SAR } & \text { Safety Analysis Report } \\ \text { SDR } & \text { System Design Requirement } \\ \text { SE } & \text { Special Equipment } \\ \text { SHP } & \text { Self-Help Program } \\ \text { SPA } & \text { Safe Plan of Action } \\ \text { SWPPP } & \text { Storm Water Pollution Prevention Plan } \\ \text { UC } & \text { University of California } \\ \text { WSS } & \text { Work Smart Standard }\end{array}$

